\title{
Immune response profiles after caterpillar exposure: a case report
}

\author{
This article was published in the following Dove Press journal: \\ Journal of Inflammation Research \\ 14 July 2010 \\ Number of times this article has been viewed
}

\author{
Tamar A Smith-Norowitz ${ }^{1,3}$ \\ Kevin B Norowitz' \\ Stephan Kohlhoff ${ }^{1,3}$ \\ Kaushal Kalra ${ }^{1,3}$ \\ Seto Chice ${ }^{2,3}$ \\ Martin H Bluth ${ }^{4}$ \\ 'Departments of Pediatrics, \\ ${ }^{2}$ Pathology, ${ }^{3}$ Center for Allergy \\ and Asthma Research, SUNY \\ Downstate Medical Center, NY, USA \\ ${ }^{4}$ Department of Pathology, Wayne \\ State University School of Medicine, \\ Detroit, MI, USA
}

Rationale: The role of the immune response to caterpillar exposure is not well described. This case study is the first to report a patient who presented with an allergic reaction after exposure to the larvae of the sycamore tussock moth, Halysidota harrisii Walsh, 1864.

Methods: Blood was collected from an allergic asthmatic adult (m/42 y/o) at $2 \mathrm{hrs}-2 \mathrm{wks}$ after contact urticaria with associated dyspnea after exposure to the larvae of the sycamore tussock moth, Halysidota harrisii Walsh, 1864. Distributions of blood lymphocytes (CD4 ${ }^{+}, \mathrm{CD}^{+}$, $\left.\mathrm{CD}^{+} \mathrm{CD}^{+} 0^{+}, \mathrm{CD} 19^{+}, \mathrm{CD} 23^{+}, \mathrm{CD} 16 / 56^{+}, \mathrm{CD} 25, \mathrm{CD} 45 \mathrm{RA}^{+}, \mathrm{CD}^{2} 5 \mathrm{RO}^{+}\right)$, monocytes $\left(\mathrm{CD} 1 \mathrm{~d}^{+}\right)$, levels of serum immunoglobulins (IgM, IgG, IgA, IgE), and cytokines (IFN- $\gamma$, IL-4, TNF- $\alpha$ ) were studied (flow cytometry, nephelometry, UniCAP Total IgE Fluoroenzymeimmunoassay, cytokine ELISA, clinical toxicology).

Results: Numbers of $\mathrm{CD}^{+} \mathrm{T}$ cells, CD25+ cells, CD19+ $\mathrm{B}$ cells, and $\mathrm{CD} 1 \mathrm{~d}^{+}$monocytes decreased $\left(22,27,33,20 \%\right.$, respectively) one week post reaction, $\mathrm{CD}_{45 \mathrm{RA}^{+} \text {naïve }}$ $\mathrm{T}$ cells decreased at 36 hours $(21 \%)$, while $\mathrm{CD} 8^{+} \mathrm{CD} 60^{+} \mathrm{T}$ cells and $\mathrm{CD} 23^{+}$cells decreased $48 \mathrm{hrs}\left(33,74 \%\right.$, respectively) post reaction. In contrast, numbers of CD $16 / 56^{+} \mathrm{NK}$ precursor cells increased (60\%) $12 \mathrm{hrs,} \mathrm{then} \mathrm{decreased} \mathrm{(65 \% )} 48 \mathrm{hrs}$ post reaction; other lymphocyte subsets were unaffected. Serum IgM, IgG and IgA were within normal range; however, serum IgE demonstrated a bimodal elevation at $2 \mathrm{hrs}(15 \%)$ and one week post reaction. Levels of IFN- $\gamma$, IL-4, and TNF- $\alpha$ were not detected in serum pre-exposure $(<1.0-4.0 \mathrm{pg} / \mathrm{mL})$. However, high levels of IFN- $\gamma(187-319 \mathrm{pg} / \mathrm{mL})$ and TNF- $\alpha(549-749 \mathrm{pg} / \mathrm{mL})$ were detected in serum 24-36 hrs and 3.5-24 hrs post reaction, respectively. In contrast, levels of IL-4 were undetected $(<1.0 \mathrm{pg} / \mathrm{mL})$ in serum at all time points.

Conclusions: Exposure to the larvae of the sycamore tussock moth, Halysidota harrisii Walsh, 1864 may result in increased cytokine levels and blood CD16/56 $6^{+} \mathrm{NK}$ precursor cells.

Keywords: caterpillar exposure, Halysidota harrisii Walsh, 1864, serum IgE

\section{Introduction}

It has been reported that caterpillar exposure results in symptoms including: local effects (dermatitis), ${ }^{1,2-5}$ local pain, ${ }^{1,6}$ and systemic effects, including anaphylaxis, depending on the species. ${ }^{1,6-9}$ Caterpillar dermatitis or lepidopterism is a toxic irritant whose reaction is triggered by the release of histamine thaumetopoein and other kinins from the hairs of caterpillars and butterflies. ${ }^{10}$ In central Europe, the two main causes of caterpillar dermatitis are the oak and pine processionary caterpillar. ${ }^{10}$ It has been observed that patients may develop cutaneous reactions, conjunctivitis, bronchitis and in some instances, anaphylactic reactions. ${ }^{10}$ With the exception of bee and wasp venom allergies, immediate-type allergic reactions to mosquitoes, flies, ticks, bed bugs, moths, caterpillars and spiders are rare. ${ }^{11}$
Correspondence: Tamar A SmithNorowitz

SUNY Downstate Medical Center,

Dept of Pediatrics, Box 49,

450 Clarkson Ave, Brooklyn, New

York II 203, USA

Tel $+|7| 82701295$

Fax +I 7I8 2703289

Email tamar.smith-norowitz@ downstate.edu 
Other studies have reported gypsy moth caterpillar dermatitis after direct contact with the first instar larva of the gypsy moth (Lymantria dispar). ${ }^{12}$ The pathogenesis of this dermatitis most likely involves histamine release by the caterpillar and a delayed hypersensitivity reaction in its host. ${ }^{12}$

Exposure to hairs from 'itchy' caterpillars are usually nonvenomous, but a contact reaction may produce mechanical irritation $^{1,13}$ and dermatitis. ${ }^{1,3,5,14}$ Studies of Vega et al have reported allergic reactions to allergens from the pine processionary caterpillar Thaumetopoea pityocampa, which induces dermatitis by a toxic-irritative mechanism; ${ }^{15}$ these reactions were confirmed by positive skin prick tests and specific $\operatorname{IgE}$ determination (immunoblot) using crude larval extracts. ${ }^{15}$ However, a specific low molecular weight $15-\mathrm{kDa}$ IgE-binding protein, Tha $\mathrm{p} 1$, was later identified as a major caterpillar allergen. ${ }^{16}$ Patients with suspected contact urticaria from pine processionary caterpillars displayed allergic reactions/ symptoms that included angiodema, conjunctivitis, and anaphylaxis. ${ }^{15}$ The wheals were localized mainly on the neck and forearms.${ }^{15}$ Cutaneous reactions to pine processionary caterpillar have also been reported in children. ${ }^{17}$ However, these cases are frequent in pinery zones, and only in some cases, due to an IgE-mediated allergic mechanism caused by pine processionary caterpillar proteins. ${ }^{17,18}$ Systemic allergic reactions to the larvae of the sycamore tussock moth, Halysidota harrisii Walsh, 1864 in humans have not been reported.

In the current study, we are the first to describe the clinical and immunological responses following contact with the larvae of the sycamore tussock moth, Halysidota harrisii Walsh, 1864, in Brooklyn, NY. Even though reactions to Lepidoptera (moths, butterflies, and caterpillars) are usually mild and self-limited, reactions in sensitive individuals and to specific species can be severe. ${ }^{19}$

Because the reported responses to caterpillar exposure are variable and the habitat of Halysidota harrisii Walsh, 1864 is prevalent in eastern parts of the United States as well as southeast regions of Canada, ${ }^{20}$ the potential importance of cells and cytokines post exposure in atopic individuals may be underrepresented. As such this case demonstrates the complexity of immune reactions to caterpillar exposure. Awareness and further understanding of caterpillar exposure may be important for atopic individuals with caterpillar sensitivity.

\section{Materials and methods Patient history}

A 42-year-old man presented to his private doctor's office (Brooklyn, NY) with a severe allergic reaction from contact with a caterpillar which fell on his arm, when he was entering his car which was parked under a tree in front of his house (Brooklyn, NY). A more detailed description of the patient's symptoms is listed in the Results section.

In order to further characterize the systemic immune response to the caterpillar, informed consent was obtained, and blood and serum samples were drawn at various time points after diagnosis (eg, 2, 3.5, 12, 24, 36, 48 hrs; 1, 2 wks).

\section{Caterpillar identification}

The caterpillar observed at the time of the exposure was obtained from the patient for identification. Identification was performed at the Dept of Entomology, Cornell University (Geneva, NY) according to standard clinical taxonomic methodology.

\section{Immunoglobulin determination}

Blood was collected and immunoglobulin (Ig) levels (IgG, IgM, IgA) were detected in serum (Quest Diagnostics, Teterboro, NJ). All serum IgE determinations were carried out in the Clinical Diagnostic Laboratory at SUNY Downstate Medical Center (UniCAP Total IgE fluoroenzymeimmunoassay, Pharmacia and Upjohn Diagnostics, Kalamazoo, MD) which was performed according to manufacturer's recommendation.

\section{Flow cytometry}

For flow cytometry studies, blood was collected into ethylenediaminetetraacetic Monoject tubes (Sherwood Medical Company, St. Louis MO) (EDTA) and retained for up to $2 \mathrm{hr}$ at room temperature.

\section{Antibodies}

Mouse antihuman monoclonal antibodies directly conjugated to fluorescein isothiocyanate (FITC) $\left(\mathrm{IgG}_{1}\right.$ anti-CD45RA, CD25, CD23; IgM anti-CD60); phycoerythrin (PE) ( $\operatorname{IgG}_{1}$ anti-CD4, CD8, CD1d; $\operatorname{IgG}_{2 \mathrm{a}}$ anti-CD45RO), Simultest (FITC/PE-conjugated) reagents $(\mathrm{CD} 3 / \mathrm{CD} 4, \mathrm{CD} 3 / \mathrm{CD} 8$, $\left.\mathrm{CD} 3 / \mathrm{CD} 19, \mathrm{CD} 3 / \mathrm{CD} 16^{+} \mathrm{CD} 56\right)$, and appropriately matched isotype control monoclonal antibodies (FITC-conjugated $\operatorname{IgG}_{1}$, PE-conjugated $\operatorname{IgG}_{1}$ and $\operatorname{IgG}_{2 \mathrm{a}}$, Simultest control $\gamma_{1} / \gamma_{2 \mathrm{a}}$, FITC-conjugated IgM). All antibodies were purchased from BD Biosciences (San Jose, CA), except IgM anti-CD60 which was purchased from Ancell, (Bayport, MN); and $\mathrm{IgG}_{1}$ anti-CD1d, which was purchased from BD Pharmingen (San Diego, CA). All were used according to manufacturers' recommendation. 


\section{Assay}

For labeling studies, conjugated antibodies $(10 \mu \mathrm{L})$ (or $80 \mu \mathrm{L}$ of titrated anti-CD60) directed against 1-3 markers, were added to blood $(100 \mu \mathrm{L})$ in $12 \times 75 \mathrm{~mm}(5 \mathrm{~mL})$ tubes (Fisher Scientific, Springfield, NJ) and incubated for 10 mins at room temperature, after which erythrocytes were lysed with whole blood lysing reagent (Immunoprep; Beckman Coulter, Hialeah, FL), and the cells counted. Lymphocyte distributions were determined with a Coulter Epics XL/MCL Flow Cytometer with System II software (Coulter), and CytoComp (Coulter) QC Windows (Flow Cytometry Systems, San Juan, Puerto Rico) used to ensure consistent instrument settings. Absolute lymphocyte numbers are calculated from the total lymphocytes. Data are expressed as total lymphocytes per cubic millimeter $\left(\mathrm{mm}^{3}\right)$ or mean percentage $(\%)$ of positive cells.

\section{Cytokine determination}

Serum cytokines (interferon gamma [IFN- $\gamma]$, interleukin-4 [IL-4], Interleukin-12 [IL-12], Tumor necrosis factoralpha $[$ TNF- $\alpha]$ ) were determined by sandwich ELISA (Biosource; Camarillo, CA) according to the manufacturer's protocol.

\section{Results}

\section{Patient symptoms}

Patient symptoms began immediately after exposure to caterpillar larvae; the local effects included redness, swelling, pain, and severe itchiness with medium size urticaria (3-5 mm with flare) on his left forearm (Figure 1), which spread to his upper chest and neck area. He complained about breathing difficulty with shortness of breath. The patient had a history of moderate asthmatic episodes (mild-intermittent) and atopy (environmental and food), with high serum IgE levels (208 IU/mL). He had no known drug allergies; his social history was unremarkable. Treatment was initiated immediately (doctor's office) (within $10-15 \mathrm{~min}$ ) with the antihistamine diphenhydramine $\mathrm{HCl}$ (75 mg po), and albuterol (mdi, 2 puffs, po). Patient's symptoms resolved uneventfully, contact urticaria and itchiness resolved 48 hrs later while breathing difficulty resolved within 1-2 hrs. No persistent symptoms were observed over the next couple of days.

\section{Taxonomic evaluation}

The caterpillar was identified as the larvae of the sycamore tussock moth, Halysidota harrisii Walsh, 1864 (Figure 2).

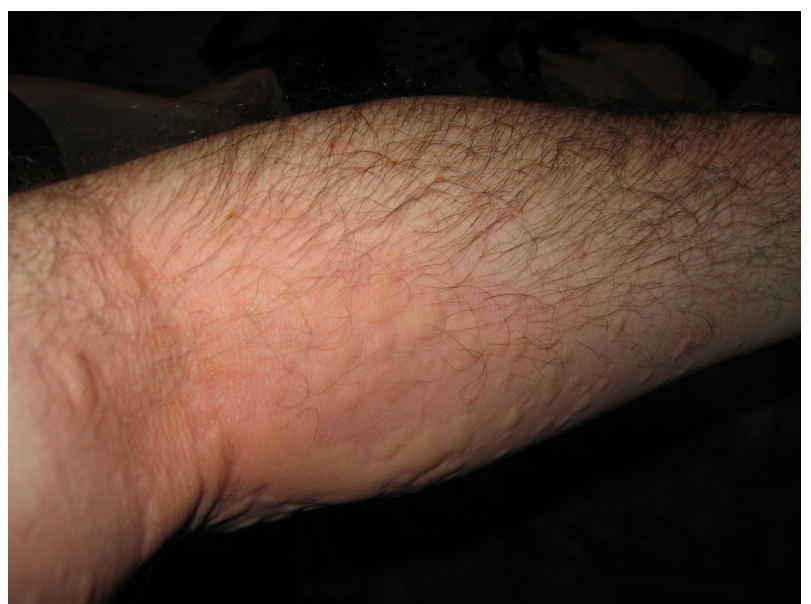

Figure I Appearance of contact exposure reaction in an allergic asthmatic patient to the larvae of the sycamore tussock moth, Halysidota harrisii Walsh, 1864. Inflammation and induration are evident in the anticubital fossa (site of catapillar exposure) with proximal and distal radiation.

\section{Serum immunoglobulins Total $\lg M, \lg G$, IgA, and $\lg \mathrm{E}$}

Serum IgM, IgG, IgA were within normal range (see materials and methods), while serum IgE levels were high. Even though no differences were observed between any of the Igs, serum IgE levels demonstrated a slight bimodal elevation at $2 \mathrm{hrs}$ and one week post reaction (Table 1).

\section{Distributions of blood lymphocyte subpopulations}

Distributions of blood lymphocytes $\left(\mathrm{CD}^{+}, \mathrm{CD}^{+}\right.$, $\mathrm{CD}^{+} \mathrm{CD}^{2} 0^{+}, \mathrm{CD}_{19}{ }^{+}, \mathrm{CD} 23^{+}, \mathrm{CD} 16 / 56^{+}, \mathrm{CD} 25, \mathrm{CD}^{2} 5 \mathrm{RA}^{+}$, $\left.\mathrm{CD} 45 \mathrm{RO}^{+}\right)$and monocytes $\left(\mathrm{CD} 1 \mathrm{~d}^{+}\right)$were studied in peripheral blood. Absolute numbers of $\mathrm{CD}^{+} \mathrm{T}$ cells, $\mathrm{CD} 25^{+}$cells, CD $19^{+} \mathrm{B}$ cells, and $\mathrm{CD} 1 \mathrm{~d}^{+}$monocytes decreased $(22,27,33,20 \%$, respectively) one week post reaction, while $\mathrm{CD} 8^{+} \mathrm{CD} 60^{+} \mathrm{T}$ cells and $\mathrm{CD} 23^{+}$cells decreased 48 hrs (33,74\%, respectively) post reaction and $\mathrm{CD}^{2} 5 \mathrm{RA}^{+}$naïve $\mathrm{T}$ cells decreased (21\%) 36 hours post

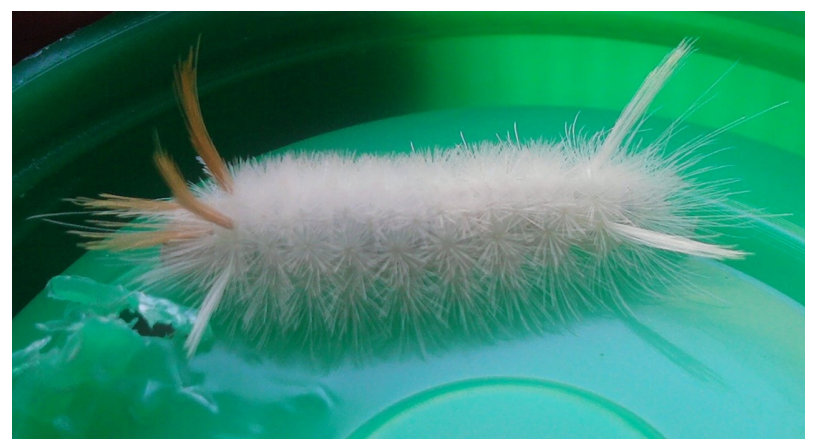

Figure 2 Picture of the larvae of the sycamore tussock moth, Halysidota harrisii Walsh, 1864 
Table I Immunoglobulin levels in serum of a patient with an allergic response to caterpillar exposure

\begin{tabular}{|c|c|c|c|c|}
\hline \multirow[t]{3}{*}{ Time } & \multicolumn{4}{|c|}{ Immunoglobulin } \\
\hline & IgM & IgG & $\operatorname{IgA}$ & IgE \\
\hline & $\overline{(\mathrm{mg} / \mathrm{dL})}$ & $\overline{(\mathrm{mg} / \mathrm{dL})}$ & $\overline{(\mathrm{mg} / \mathrm{dL})}$ & (IU/mL) \\
\hline Pre & 54 & 725 & 322 & 181 \\
\hline $2 \mathrm{hrs}$ & 47 & 815 & 339 & 208 \\
\hline $3.5 \mathrm{hrs}$ & 52 & 753 & 317 & 182 \\
\hline $12 \mathrm{hrs}$ & 52 & 760 & 324 & 193 \\
\hline 24 hrs & 69 & 817 & 337 & 184 \\
\hline $36 \mathrm{hrs}$ & 55 & 805 & 349 & 198 \\
\hline $48 \mathrm{hrs}$ & 55 & 755 & 323 & 188 \\
\hline I wk & 54 & 798 & 337 & 202 \\
\hline 2 wks & 55 & 760 & 318 & 191 \\
\hline
\end{tabular}

Notes: Immunoglobulin levels in a serum $\mathrm{IgE}^{+}$allergic asthmatic adult, before (pre) and after (2, 3.5, I2, 24, 36, 48 hrs and I-2 wks) an allergic response to caterpillar hair (from the larva of the sycamore tussock moth, Halysidota harrisii Walsh, 1864), as determined by Quest Diagnostics (Nephelometry, ELISA). Data are expressed as either $\mathrm{mg} / \mathrm{dL}$ or $\mathrm{IU} / \mathrm{mL}$. Quest Diagnostics reference range for healthy adult serum: IgM: 47-367 mg/dL; IgG: 648-2045 mg/dL; IgA: 55-375 mg/dL; IgE: $20-100 \mathrm{lU} / \mathrm{mL}$.

reaction (Tables 2, 3). In contrast absolute numbers of CD16/56 ${ }^{+}$NK precursor cells increased (60\%) $12 \mathrm{hrs,} \mathrm{then}$ decreased (65\%) $48 \mathrm{hrs}$ post reaction; other lymphocyte subsets were unaffected.

\section{Cytokines in serum}

Levels of IFN- $\gamma$, IL-4, and TNF- $\alpha$ were not detected in serum pre-exposure $(<1.0-4.0 \mathrm{pg} / \mathrm{mL})$. However, high levels of IFN- $\gamma(187-319 \mathrm{pg} / \mathrm{mL})$ and TNF- $\alpha(549-749 \mathrm{pg} / \mathrm{mL})$ were detected in serum 24-36 hrs and 3.5-24 hrs post reaction, respectively (Figure 3). In contrast, levels of IL-4 were undetected $(<1.0 \mathrm{pg} / \mathrm{mL})$ in serum at all time points. All cytokines returned to baseline levels one year post reaction (Figure 3).

\section{Discussion}

This is the first study of an allergic reaction resulting from caterpillar exposure that demonstrates that contact/exposure to the larvae of the Halysidota harrisii Walsh, 1864. The sycamore tussock moth (Halysidota harrisii) is a species of moth of the Arctiidae family, which is found in southeastern Canada and the eastern parts of the United States. ${ }^{20}$ Depending on its location, the moth flies either from May to June or from July to August, ${ }^{20}$ the latter which was reported in our study. Larvae are typically very hairy, ${ }^{20}$ as observed (Figure 2). Systemic allergic responses to contact reactions with the larvae of Halysidota harrissii have not been previously described.

Studies of Maier et al have reported dermatitis in children who came in contact with the urticating haris (setae) of oak processionary caterpillars, the larvae of Thaumetopoea processionea L., in a suburb of Vienna. ${ }^{21}$ An increase in the number of cases of reported lepidopterism, an airborne disease caused by the setae of the oak processionary caterpillar, has caused public health concerns. ${ }^{22}$ Studies of Jans and Franssen ${ }^{23}$ described direct animal exposure to the urticating hairs of the oak processionary caterpillar due to ingestion and inhalation; symptoms included labial angioedema, ptyalism, sloughing, tongue swelling, stomatitis, conjunctivitis and respiratory distress. ${ }^{23}$

Other caterpillars, including the pine processionary caterpillar, which is responsible for dermatitis, contact urticaria, and, rarely, respiratory and anaphylactic reactions through IgE-mediated or non-IgE-mediated mechanisms, ${ }^{24}$ can also cause significant local reactions and airway swelling if ingested. ${ }^{24}$ Accidents with the caterpillar Lonomia obliqua have been described, which are associated with a coagulation disorder and hemorrhagic syndrome in humans, caused by envenomation with this caterpillar. ${ }^{25}$ Antivenin is available in the case of potentially fatal Lonomia envenomation. ${ }^{19}$

In general, lepidopterism outbreaks are rare. ${ }^{26}$ However, Redd et $\mathrm{a}^{26}$ investigated a lepidopterism outbreak associated

Table 2 Distributions of lymphocyte subpopulations in peripheral blood of a patient with an allergic response to caterpillar hair

\begin{tabular}{|c|c|c|c|c|c|c|c|c|c|c|c|c|}
\hline \multirow[t]{2}{*}{ Time } & \multicolumn{2}{|c|}{$\mathrm{CD3}^{+} \mathrm{CD4}^{+}$} & \multicolumn{2}{|c|}{$\mathrm{CD3}^{+\mathrm{CD}^{+}}{ }^{+}$} & \multicolumn{2}{|c|}{$\mathrm{CD}^{+} \mathrm{CD}^{-} 0^{+}$} & \multicolumn{2}{|c|}{$\mathrm{CD} 16^{+} 56^{+}$} & \multicolumn{2}{|c|}{$\mathrm{CD} \mathbf{9}^{+}$} & \multicolumn{2}{|c|}{$\mathrm{CD}^{2} 3^{+}$} \\
\hline & $(\%)$ & $\mathrm{mm}^{3}$ & $(\%)$ & $\mathrm{mm}^{3}$ & $(\%)$ & $\mathrm{mm}^{3}$ & $(\%)$ & $\mathrm{mm}^{3}$ & (\%) & $\mathrm{Mm}^{3}$ & $(\%)$ & $\mathrm{mm}^{3}$ \\
\hline $2 \mathrm{hrs}$ & 51 & 1049 & 28 & 575 & 6.0 & 130 & 3.0 & 58 & 12 & 250 & 2.0 & 38 \\
\hline $3.5 \mathrm{hrs}$ & 51 & 1049 & 29 & 594 & 7.0 & 140 & 3.0 & 51 & 12 & 254 & 1.0 & 23 \\
\hline $12 \mathrm{hrs}$ & 48 & 975 & 29 & 588 & 6.0 & 114 & 7.0 & 146 & 10 & 200 & 1.0 & 19 \\
\hline $24 \mathrm{hrs}$ & 54 & 1096 & 27 & 547 & 6.0 & 122 & 3.0 & 71 & 11 & 215 & 1.0 & 20 \\
\hline $36 \mathrm{hrs}$ & 48 & 979 & 29 & 586 & 7.0 & 139 & 6.0 & 114 & II & 223 & 1.0 & 13 \\
\hline $48 \mathrm{hrs}$ & 54 & 1106 & 26 & 541 & 4.0 & 86 & 3.0 & 51 & 14 & 289 & 0.5 & 10 \\
\hline I wk & 48 & 818 & 32 & 553 & 9.0 & 162 & 4.0 & 76 & 10 & 170 & 1.0 & 23 \\
\hline 2 wks & 46 & 950 & 31 & 639 & 8.0 & 160 & 4.0 & 77 & 11 & 233 & 0.4 & 9.0 \\
\hline
\end{tabular}

Notes: The distributions of lymphocyte subpopulations in peripheral blood of a serum IgE ${ }^{+}$allergic asthmatic adult after (2, 3.5, I2, 24, 36, 48 hrs and I-2 wks) an allergic response to caterpillar hair (from the larva of the sycamore tussock moth, Halysidota harrisii Walsh, 1864). Data are expressed as mean total cells/mm ${ }^{3}$ or mean percentage (\%) of positive cells. 
Table 3 Distributions of lymphocyte subpopulations in peripheral blood of a patient with an allergic response to caterpillar exposure

\begin{tabular}{|c|c|c|c|c|c|c|c|c|c|c|}
\hline \multirow[t]{2}{*}{ Time } & \multicolumn{2}{|c|}{$\mathrm{CD}^{2} 5^{+}$} & \multicolumn{2}{|c|}{$\mathrm{CD4}^{+} \mathrm{CD}^{25^{+}}$} & \multicolumn{2}{|c|}{${\text { CD45 } \text { RA }^{+}}^{-}$} & \multicolumn{2}{|c|}{$\mathrm{CD} 4 \mathrm{RO}^{+}$} & \multicolumn{2}{|c|}{$\begin{array}{l}\text { CDId }^{+} \\
\text {monocytes) }\end{array}$} \\
\hline & (\%) & $\mathrm{mm}^{3}$ & (\%) & $\overline{\mathbf{m m}^{3}}$ & (\%) & $\overline{\mathbf{m m}^{3}}$ & (\%) & $\overline{\mathbf{m m}^{3}}$ & (\%) & $\mathrm{mm}^{3}$ \\
\hline $2 \mathrm{hrs}$ & 5.0 & 112 & 0 & 0 & 37 & 750 & 66 & 1343 & 90 & 1835 \\
\hline $3.5 \mathrm{hrs}$ & 6.0 & 127 & 0 & 0 & 36 & 730 & 65 & 1339 & 92 & 1892 \\
\hline $12 \mathrm{hrs}$ & 5.0 & 97 & 0 & 0 & 37 & 764 & 64 & 1307 & 88 & 1808 \\
\hline $24 \mathrm{hrs}$ & 6.0 & 124 & 0 & 0 & 35 & 713 & 69 & 1409 & 92 & 1886 \\
\hline $36 \mathrm{hrs}$ & 4.0 & 86 & 0 & 0 & 23 & 479 & 67 & 1366 & 85 & 1745 \\
\hline $48 \mathrm{hrs}$ & 7.0 & 136 & 0 & 0 & 35 & 713 & 66 & 1349 & 85 & 1746 \\
\hline I wk & 5.0 & 82 & 0 & 0 & 35 & 595 & 70 & 1203 & 85 & $|46|$ \\
\hline 2 wks & 5.0 & 104 & 0 & 0 & 33 & 676 & 68 & 1395 & 86 & 1767 \\
\hline
\end{tabular}

Notes: The distributions of lymphocyte subpopulations (activation and memory markers) in peripheral blood of a serum lgE allergic asthmatic adult after (2, 3.5, I2, 24, 36, 48 hrs and I-2 wks) an allergic response to caterpillar hair (from the larva of the sycamore tussock moth, Halysidota harrisii Walsh, I864). Data are expressed as mean total cells $/ \mathrm{mm}^{3}$ or mean percentage $(\%)$ of positive cells.

with caterpillars of the Douglas-fir tussock moth (Orgyia pseudotsugata) at a Boy Scout summer camp in New Mexico. Contact exposure included symptoms of itch, rash, or hives. ${ }^{26}$ The authors concluded that avoiding areas of heavy infestation can reduce illness risk, as well as modifying behaviors
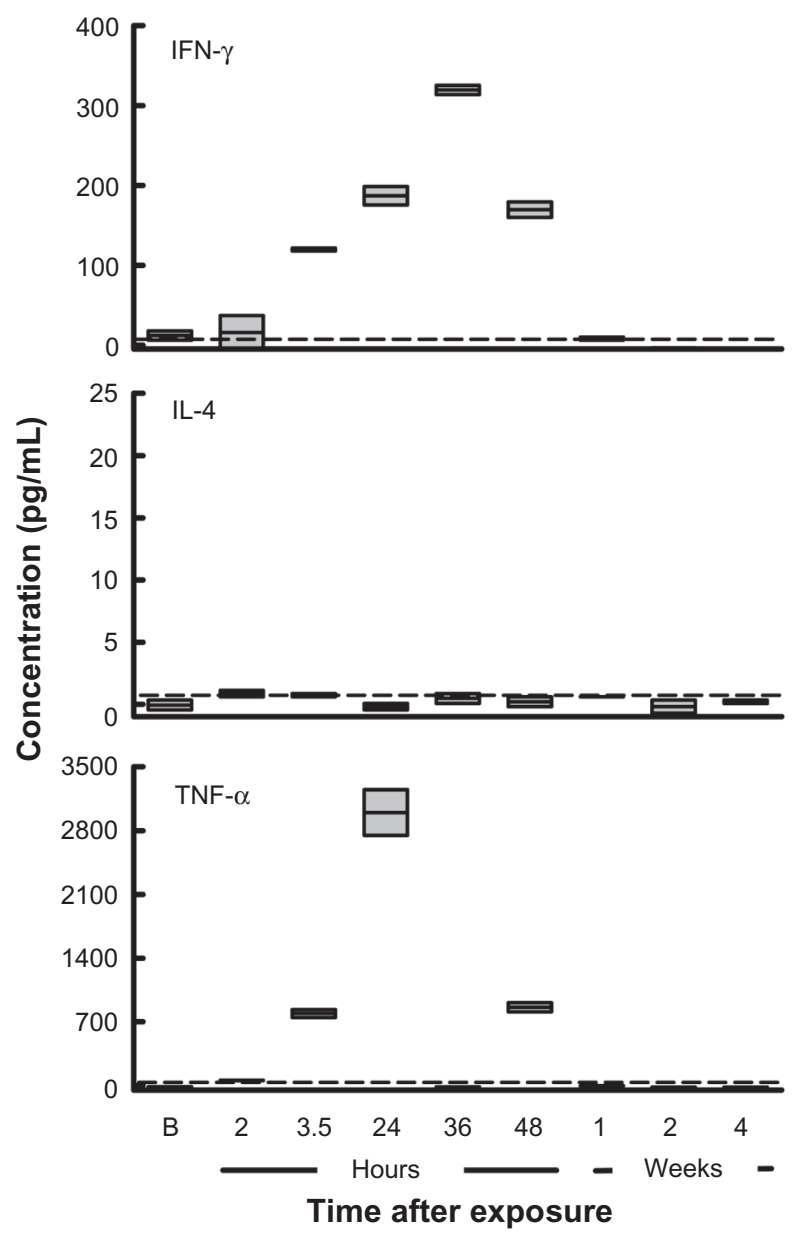

Figure 3 Serum levels ( $\mathrm{pg} / \mathrm{mL}$ ) of cytokines (IFN- $\gamma$, IL-4, TNF- $\alpha$ ) determined by ELISA in patient after immune response to caterpillar exposure $(2-48 \mathrm{hrs}$, I-4 weeks post exposure). Dashed line indicates the assay detection threshold based on calibration curves. associated with lepidopterism. ${ }^{26}$ Allergic reactions to Lepidoptera can be treated with removal of offending hairs, followed by topical steroids, and oral antihistamines. ${ }^{19}$

In the present study, our patient suffered a severe allergic reaction when he came in contact with the larva from the Halysidota harrisii Walsh. While we did not obtain serum tryptase levels in order to confirm anaphylaxis, the rapid development of contact urticaria and acute asthma are consistent with a systemic type 1 allergic response.

Our subject, an allergic asthmatic who had elevated serum $\operatorname{IgE}(>100 \mathrm{IU} / \mathrm{mL})$, had normal immunoglobulin levels (IgG, IgM, IgA). However, his serum IgE levels slightly increased (15\%), $2 \mathrm{hrs}$ and then again one week post exposure. Numbers of blood CD16/56 $6^{+} \mathrm{NK}$ precursor cells increased (60\%) $12 \mathrm{hrs}$ post exposure, and then decreased (65\%) 48 hrs post reaction. Further, the observed decreases in absolute numbers of $\mathrm{T}$ and $\mathrm{B}$ cell subsets at one week with yet earlier decreases (48 hours post reaction) occurring for $\mathrm{CD}^{+} \mathrm{CD}^{+} 0^{+} \mathrm{T}$ cells and $\mathrm{CD} 23^{+}$cells may relate to a cellular interplay pertaining to $\mathrm{IgE}$ modulation. Earlier work in our laboratory has demonstrated the presence of $\mathrm{CD}^{+} \mathrm{CD} 60^{+}$ $\mathrm{T}$ cells in the placenta of twins with a family history of asthma and atopy. ${ }^{27}$ Others have shown that $\mathrm{CD} 23^{+}$cells, which express the low affinity receptor for IgE (FceRII), can be activated by IgE sensitization and potentiate TNF $\alpha$ and MIP-1 $\alpha$ cytokine expression. ${ }^{28}$ The stoichiometric relationship between changes in immune cell subsets, IgE/antigen specific IgE and clinical severity after caterpillar exposure remains to be determined.

Serum IFN- $\gamma$ levels were high, but IL-4 was not detected, postulating a non-IL-4-mediated allergic response. It is well known that IgE can survive without allergen contact for long periods bound to Fc receptors of mast cells or basophilic granulocytes. ${ }^{29}$ It could be that our patient was presensitized to caterpillar antigen, and that exposure induced mast cell 
degranulation and induction of massive IFN- $\gamma$ levels but total serum IL-4 and IgE levels remained basically low or unchanged, due to cross linking, not induction. The levels of TNF- $\alpha$ observed may result from mast cell degranulation, maybe in the early phase and late phase reactions but may also be in response to direct sensitization of $\operatorname{IgE} .^{28}$ It could be that our patient demonstrated an allergic reaction to the larva, either by direct contact with hair or other proteinaceous components, which was induced by a non IgE-dependent mechanism that had a mast-cell dependent mechanism. However, the molecular mechanisms underlying the inflammatory effect of caterpillar antigen(s) remain to be elucidated.

As a case study of a single subject, this study has other limitations including the lack of confirmation of anaphylaxis as tryptase levels were not obtained, possible affects of antihistamine therapy on the immune response, and the lack of confirmation of IgE anti-larvae by classical methods (ELISA, Western blot). Finally, the lack of standardized caterpillar extract for skin testing and for the determination of specific IgE. ${ }^{11}$ Nonetheless, since severe responses to caterpillar exposure are infrequent and vary based on species, continued awareness is critical to further the understanding of such responses.

In summary, our descriptive data provides detailed information on the immune response to the larvae of the sycamore tussock moth, Halysidota harrisii Walsh, 1864. Even though these exposures may be uncommon, it is important to recognize the potential clinical sequelae, including anaphylaxis, of contact with these larvae. Further, since the habitat of Halysidota harrisii Walsh, 1864 comprises eastern regions of the United States and southeastern Canada, the paucity of reports could be due to under-representation. Although our findings are based on one patient and extrapolation of the immunological findings to other patients or to other species of caterpillar would be premature, increased awareness of caterpillar exposure in atopic individuals may prove useful in identifying caterpillar sensitivities and clinical sequelae related to such exposure.

\section{Acknowledgment}

We express our appreciation to Dr Paul Robins, PhD, Dept of Entomology, Cornell University (Geneva, NY) for his contribution to the study.

\section{Disclosure}

The authors declare no competing financial interest.

\section{References}

1. Balit CR, Geary MJ, Russell RC, Isbister GK. Prospective study of definite caterpillar exposure. Toxicon. 2003;42(6):657-662.

2. Burdmann EA, Antunes I, Saldanha LB, Abdulkader RCMR. Severe acute renal failure induced by the venom of Lonomia caterpillars. Clin Nephrol. 1996;46(5):337-339.

3. Cleland JB. Papulo-urticarial rashes caused by the hairlets of caterpillars of the moth (Euproctis edwardsi newm). Med J Aust. 1920; $1: 169-170$.

4. Scholz A, Russell R, Geary M. Investigation of caterpillar dermatitis in school children. N.S.W. Public Health Bull. 1993;4(6):65-66.

5. Balit CR, Geary MJ, Russell RC, Isbister GK. Clinical effects of exposure to the white-stemmed gum moth (Chelepteryx collesi). Emerg Med Australas. 2004;16(1):74-81.

6. Everson GW, Chapin JB, Normann SA. Caterpillar envenomations: a prospective study of 112 cases. Vet Human Toxicol. 1990;32(2):114-119.

7. Arocha-Pinango CL, de Bosch NB, Torres A, et al. Six new cases of a caterpillar-induced bleeding syndrome. Thromb Haemost. 1992;67(4): 402-407.

8. Balit CR, Ptolemy HC, Geary MJ, Russell RC, Isbister GK. Outbreak of caterpillar dermatitis caused by airborne hairs of the mistletoe browntail moth (Euproctis edwardsi). Med J Aust. 2001;175:641-643.

9. Isbister GK, Gray MR. A prospective study of 750 definite spider bites, with expert spider identification. QJM. 2002;95(11):723-731.

10. Utikal J, Booken N, Peitsch WK, Kemmler N, Goebeler M, Goerdt S. Caterpillar dermatitis: an increasing dermatologic problem in warmer regions of Germany. Hautarzt. 2009;60(1):48-50.

11. Bircher AJ. Systemic immediate allergic reactions to arthropod stings and bites. Dermatology. 2005;210(2):119-127.

12. Allen VT, Miller OF 3rd, Tyler WB. Gypsy moth caterpillar dermatitis revisited. J Am Acad Dermatol. 1991;24(6 Pt 1):979-981.

13. Isbiter GK, Whelan PI. Envenomation by the billygoat plum stinging caterpillar (Thosea penthima). Med J Aust. 2000;173(11/12):654-655.

14. Pitetti RD, Kuspis D, Krenzelok EP. Caterpillar: an unusual source of ingestion. Pediatr Emerg Care. 1999;15(1):33-36.

15. Vega JM, Moneo I, Armentia A, Vega J, De la Fuente R, Fernandez A. Pine processionaray caterpillar as a new cause of immunologic contact urticaria. Contact Dermatitis. 2000;43(3):129-132.

16. Moneo I, Vega JM, Caballero ML, Vega J, Alday E. Isolation and characterization of Tha $\mathrm{p} 1$, a major allergen from the pine processionary caterpillar Thaumetopoea pityocampa. Allergy. 2003;58(1):34-37.

17. Vega ML, Vega J, Vega JM, Moneo I, Sanchez E, Miranda A. Cutaneous reactions to pine processionary caterpillar (Thaumetopoea pityocampa) in pediatric population. Pediatr Allergy Immunol. 2003;14(6):482-486.

18. Fuentes Aparicio V, Zapatero Remon L, Martinez Molero MI, Alonso Lebreros E, Beitia Mazuecos JM, Bartolome Zavala B. Allergy to pine processionary caterpillar (Thaumetopoea pityocampa) in children. Allergol Immunopathol (Madr). 2006;34(2):59-63.

19. Hossler EW. Caterpillars and moths. Dermatol Ther. 2009;22(4): 353-366.

20. Wagner DL. Caterpillars of Eastern North America: A guide to identification and natural history (Princeton Field Guides). Princeton, NJ: Princeton University Press, 2005:443-450.

21. Maier H, Speigel W, Kinaciyan T, Honigsmann H. Caterpillar dermatitis in two siblings due to the larvae of Thaumetopoea processoinea L., the oak processionary caterpillar. Dermatology. 2004;208(1):70-73.

22. Gottschling S, Meyer S. An epidemic airborne disease caused by the oak processionary caterpillar. Pediatr Dermatol. 2006;23(1):64-66.

23. Jans HW, Franssen AE. The urticating hairs of the oak processionary caterpillar (Thaumetopoea processionea L.), a possible problem for animals? Tijdschr Diergeneeskd. 2008;133(10):424-429.

24. Inal A, Altintas DU, Guvenmez HK, Yilmaz M, Kendirli SG. Life-threatening facial edema due to pine caterpillar mimicking an allergic event. Allergol Immunopathol (Madr). 2006;34(4):171-173. 
25. Veiga AB, Ribeiro JM, Guimaraes JA, Francischetti IM. A catalog for the transcripts from the venomous structures of the caterpillar Lonomia oliqua: identification of the proteins potentially involved in the coagulation disorder and hemorrhagic syndrome. Gene. 2005;355:11-27.

26. Redd JT, Voorhees RE, Torok TJ. Outbreak of lepidopterism at a Boy Scout camp. J Am Acad Dermatol. 2007;56(6):952-955.

27. Smith-Norowitz TA, Norowitz K, Silverberg J, et al. CD $8^{+} \mathrm{CD} 60^{+} \mathrm{T}$ cells, cells expressing epsilon specific mRNA, and Th1/Th2 cytokines in cord blood and at 7 months of age. Scand J Immunol. 2008;68:526-533.
28. Ezeamuzie CI, Al-Attiyah R, Shihab PK, Al-Radwan R. Low-affinity IgE receptor (FcepsilonRII)-mediated activation of human monocytes by both monomeric IgE and IgE/anti-IgE immune complex. Int Immunopharmacol. 2009;9:1110-1114.

29. Asai K, Kitaura J, Kawakami Y, et al. Regulation of mast cell survival by IgE. Immunity. 2001;14:791-800.

\section{Publish your work in this journal}

The Journal of Inflammation Research is an international, peer-reviewed open-access journal that welcomes laboratory and clinical findings on the molecular basis, cell biology and pharmacology of inflammation including original research, reviews, symposium reports, hypothesis formation and commentaries on: acute/chronic inflammation; mediators of inflamma-

\section{Dovepress}

tion; cellular processes; molecular mechanisms; pharmacology and novel anti-inflammatory drugs; clinical conditions involving inflammation. The manuscript management system is completely online and includes a very quick and fair peer-review system. Visit http://www.dovepress.com/ testimonials.php to read real quotes from published authors.

\footnotetext{
Submit your manuscript here: http://www.dovepress.com/journal-of-inflammation-research-journal
} 